\title{
Pemanfaatan Limbah Plastik Dan Limbah Kayu Sebagai Bahan Komposit Kayu Plastik Untuk Melapisi Produk Interior Dan Eksterior Pada Rumah Tangga
}

\author{
Fulan Miftahul Janah \\ Mahasiswa program studi Fisika FMIPA Universitas Sebelas Maret \\ Jl. Ir Soetami, Jebres, Surakarta, Jawa Tengah, Indonesia
}

\section{A. PENDAHULUAN}

Kayu merupakan bahan yang paling banyak ditemukan dan digunakan untuk keperluan kontruksi. Kebutuhan kayu yang terus meningkat berbanding terbalik dengan potensi hutan yang terus berkurang. Karena hal inilah penggunaan kayu dituntut agar efisien, salah satu cara penggunaan kayu yang efisien adalah dengan memanfaatkan limbah serbuk kayu yang tidak terpakai menjadi produk yang lebih bermanfaat.

Pencemaran lingkungan yang disebabkan oleh sampah terutama sampah plastik adalah hal yang tidak bisa dihindari lagi saat ini. Dengan menggunakan metode daur ulang yang merupakan salah satu metode kreatif yang bisa dilakukan untuk mengurangi limbah plastik yang semakin hari jumlahnya terus bertambah. Limbah plastik tersebut dapat di daur ulang menjadi bahan baku anyaman pengganti material alam seperti pandan yang sudah mulai berkurang dan susah dicari saat ini dan juga dapat dijadikan alternatif bahan pelapis atau upholstery pada produk interior. Proses pengolahan limbah plastik hingga siap pakai juga lebih mudah dilakukan dibandingkan pengolahan bahan baku yang berasal dari alam karena tidak melalui banyak tahapan seperti proses pengeringan dan pewarnaan (Sofiana, 2010).

Produksi sampah di Indonesia mencapai 65 juta ton per tahun. Sebanyak 10,4 juta ton atau 16 persen merupakan sampah plastik. Dari 10,4 juta ton itu, sampah yang didaur ulang hampir 1 juta ton atau sekitar 9 persen dan yang dibakar sekitar 1,2 juta ton atau sekitar 12 persen. Artinya, 8,2 juta ton atau 79 
persen sampah plastik berakhir begitu saja di TPA maupun tempat umum seperti pantai (Sartika, 2019).

Selain itu plastik juga memiliki salah satu sifat yang sangat merugikan lingkunggan yang ada disekitarnya, yaitu sebagian besar plastik sulit terurai kembali ketika sudah tidak terpakai dan dibuang di tempat pembuangan akhir (TPA). Maka dari itu diperlukan suatu upaya agar limbah-limbah plastik yang sangat banyak itu dapat dimanfaatkan didalam kehidupan sehari-hari. Salah satu upaya yang dapat dilakukan adalah dengan mengolah limbah plastik yang tidak terpakai menjadi bahan komposit yang dapat dimanfaatkan lagi.

Perkembangan teknologi khususnya dibidang papan komposit, telah menghasilkan produk komposit yang merupakan gabungan antara serbuk kayu dengan plastik daur ulang. Teknologi ini berkembang pada awal tahun 1990-an di Jepang dan Amerika Serikat. Dengan teknologi ini dimungkinkan pemanfaatan serbuk kayu dan plastik daur ulang secara maksimal, dengan demikian akan menekan jumlah limbah yang dihasilkan.

\section{B. GAGASAN}

\section{Jenis Plastik}

Plastik yang beredar luas dimasyarakat pada saat ini terdapat berbagaimacam jenisnya. Jika didasarkan sifat fisik yang dimiliki oleh plastik itu sendiri plastik dapat digolongkan menjadi dua jenis, yaitu plastik jenis termo plastik dan plastik jenis termoset. Termoplastik adalah jenis plastik yang mana bila dipanaskan tidak merusak molekul-molekulnya, sehingga jenis plastik ini dapat dimanfaatkan lagi atau didaur ulang dengan cara dipanaskan kembali. Jenis plastik inilah yang selalu digunakan dalam proses daur ulang plastik. Sedangkan jenis plastik termoset adalah jenis plastik yang mana bila dipanaskan akan merusak molekul-molekul plastik itu sendiri, sehingga jenis plastik ini tidak dapat didaur ulang dengan cara dipanaskan kembali.

\section{Kelebihan Komposit Kayu Plastik}


Bahan komposit kayu plastik memiliki banyak kelebihan antara lain adalah:

1. Ramah lingkungan

2. Dapat didaur ulang

3. Dapat digunakan didalam dan diluar rumah

4. Tahan terhadap panas

5. Ekonomis

6. Tahan lama

7. Memiliki nilai estetika yang tinggi

8. Tahan terhadap jamur

9. Ringan

10. Tidak memerlukan perawatan yang sulit

\section{Jenis Komposit Kayu Plastik}

Penggolongan jenis komposit kayu plastik berdasarkan bentuknya dapat dibagi menjadi dua, yaitu :

1. Komposit Kayu Plastik Hollow

Komposit Kayu Plastik Hollow adalah kayu komposit yang berlubang, biasanya dipakai untuk pagar, decking, dinding,plafon,dll.

2. Komposit Kayu Plastik Solid

Komposit Kayu Plastik Solid adalah kayu komposit yang berisi persis seperti kayu asli (tidak terdapat lubang). Ketika dipegang dan diangkat terkesan berat, keras, dan kokoh. Yang mana jenis ini sering dijumpai dalam bentu papan (Wahyudi, 2015).

\section{Proses Pembuatan Komposit Kayu Plastik}

Proses pembuatan komposit kayu plastik diawali dengan pemilihan plastik dan kayu yang akan digunakan. Karena tujuan awal dari pembuatan komposit ini adalah untuk memanfaatkan limbah plastik dan juga limbah kayu, maka digunakanlah limbah plastik dengan jenis plastik termoplastik. Pemilihan jenis plastik ini dikarenakan plastik jenis ini bisa dibentuk dengan mudah dengan teknik pemanasan dan tanpa merusak molekul-molekul pada plastik itu sendiri. 
Untuk pemilihan kayu dipilih limbah kayu sisa dari industri furnitur yang menjadi penyumbang terbesar limbah kayu. Kayu yang digunakan dihaluskan terlebih dahulu, hal ini bertujuan agar campuran plastik dan kayu nantinya dapat tercampur dengan sempurna. Setelah itu mulailah proses pembuatan komposit kayu plastik yang terbagi menjadi dua tahapan. Tahapan pertama adalah tahapan komponding atau disebut juga dengan proses pencampuran.

Pada tahap pertama ini pencampuran dilakukan dengan cara memanaskan limbah plastik yang telah dipilih hingga meleleh, kemudian ketika plastik sudah meleleh lelehan ini dicampurkan dengan limbah kayu (yang telah dihaluskan) hingga merata seluruhnya. Kemudian memasuki tahapan kedua yaitu campuran plastik dan kayu dimasukkan kedalam cetakan dan kemudian dibiarkan hingga dingin dan komponen mengeras. Kemudian komposit plastik kayu siap digunakan dan dibentuk sesuai dengan kebutuhan.

\section{Aplikasi Komposit Kayu Plastik}

Dalam kehidupan sehari-hari komposit kayu plastik dapat digunakan sebagai bahan pelapis produk interior dan eksterior rumah tangga, diantaranya adalah sebagai pelapis dinding interior dan pelapis lantai outdoor.

\section{Kesimpulan}

Pemanfaatan limbah plastik dan limbah kayu sebagai bahan komposit kayu plastik untuk melapisi produk interior dan ekterior pada rumah tangga adalah salah satu cara yang efektif untuk menanggulangi permasalahan sampah yang cukup meresahkan di Indonesia ini. Dengan cara ini jumlah limbah plastik dapat ditekan karena dijadikan bahan baku pembuatan komposit. Selain itu dapat pula menekan penggunaan kayu pada produk interior dan eksterior, dan tentunya dengan adanya komposit kayu plastik ini menjadi lebih ramah lingkungan, karena selain menggurangi limbah plastik yang susah terurai juga menggurangi limbah kayu sisa yang dapat menekan penebangan pohon.

Selain ramah lingkungan pemanfaatan limbah plastik dan limbah kayu sebagai bahan komposit kayu plastik untuk melapisi produk interior dan eksterior pada rumah tangga ini juga bernilai ekonomis. Yang mana komposit kayu plastik 
ini lebih murah dibandingkan harga kayu alami yang ada dipasaran, dan juga bahan baku pembuatan komposit ini murah dan mudah untuk didpatkan karena berasal dari limbah yang pada umumnya tidak terpakai lagi dan dibuang begitu saja tanpa diolah lagi terlebih dahulu.

\section{Daftar Pustaka}

Sartika, R. E. (2019, Februari 21). Sains Kompas.com. Diambil kembali dari Kompas.com: https://sains.kompas.com/read/2019/02/21/150200523/haripeduli-sampah-nasional--5-fakta-ancaman-nyata-sampah-diindonesia?page $=$ all.

Sofiana, Y. (2010). Pemanfaatan Limbah Plastik Sebagai Alternatif Bahan Pelapis (upholstery) Pada Produk Interior. INASEA, 96-102. 